\title{
Mediating Roles of Customer Experience on E-Loyalty
}

\author{
Uppala Amulya*
}

\section{Abstract}

The purpose of this paper is to investigate the measure of customer allegiance towards e-commerce websites. This paper also examines the satisfaction level of the customers and e-trust towards e-commerce websites through a mediating role of customer experience. A conceptual model with a theoretical basis in the e-loyalty is developed to illuminate the antecedents of customer experience. In this article, an epigrammatic approach is adopted to explore the accuracies of the observations by empirical evidence. The results are expected to reveal the substantiality of customer experience and customer gratification towards e-loyalty.

Keywords: Customer Experience, E-Loyalty, Customer Gratification, Customer allegiance

\section{Introduction}

\subsection{Theoretical Background}

Customer loyalty has been studied in various fields and contexts. The concept of loyalty generally is defined as a commitment to consistently revisit a site or repurchase an item or service from the same company, without switching to other companies (Oliver, 1997). This definition has been well-accepted among practitioners and academics. However, with the emergence of e-commerce, researchers have extended the concept of loyalty into the context of the online environment, renaming it e-loyalty. This development is

* Overlook Medical Center: Summit, USA; uppala1amulya@gmail.com 
important because e-loyalty is slightly different from loyalty in the offline business context (Horppu et al., 2008; Shankar et al., 2003). Prior studies defined e-loyalty as a commitment to consistently revisit a website because of a preference for shopping from that website without switching to other websites (Cyr, 2008; Flavián et al., 2006). But this paper attempts to understand the mediating role of customer experience on E-Loyalty. Most of the researches focussing on E-Loyalty have studied the issue of how to foster and/or improve E-Loyalty (Cyr, 2008; Doong et al., 2008; Gommans et al., 2001; Harris and Goode, 2004; Jin et al., 2008; Wolfinbarger and Gilly, 2003). These studies have found that esatisfaction and e-trust are the two most important antecedents of e-loyalty.

\subsection{Problem Statement}

This research is conducted to solve the problem of customer loyalty towards e-commerce providers or sites. Due to the changes in the dynamics of the market place loyalty of the customers is getting vulnerable. Especially in e-businesses, it has become difficult to retain customer base. Customer's loyalty is being influenced by many factors. Thus, the paper tries to understand the role of customer satisfaction and e-trust towards e-loyalty, with many factors influencing them. Even the mediating role of customer experience on e-trust and customer satisfaction towards e-loyalty requires to be measured for understanding the issue.

\subsection{Purpose of the Study}

With growing technology, e-businesses have come into existence and became a vital part of the market. The purpose of this research is to examine the factors that affect e-loyalty and also measure the mediating role of customer experience on e-loyalty. This will help e-businesses to understand the customer expectations easily and meet those expectations to retain their customers by implementing sustainable business practices.

\subsection{Objectives of the Study}

The main objective of this course is to explore the role of e-trust and customer satisfaction towards e-loyalty. The other objective is 
to measure the mediating role of customer experience on e-trust and customer satisfaction towards e-loyalty.

\subsection{Scope of the Study}

In customer-centric market, e-businesses have to understand the customer and their expectations. The scope of this paper is to help e-businesses build a relationship with their customers and ensure service quality that will make the consumer re-purchase from them. This will increase loyalty and also generate more profits, making the business sustainable due to increased profits.

\subsection{Research Question}

1. What will be the mediating effects of customer experience on e-trust and customer satisfaction towards e-loyalty?

2. What will be the role of e-trust and customer satisfaction towards e-loyalty?

\section{Literature Review}

Valvi et al. (2012) stated that e-loyalty is "the customer's positive attitude towards e-commerce, resulting in repeat purchasing behaviour". It embraces high-quality customer support, on-time delivery, obligating product presentations online (website design and proper product information), convenient and reasonably priced shipping and handling costs (switching costs), trustworthy privacy and security policies. As a result, the study of e-loyalty's antecedents has become essential; satisfaction, trust, delivery efficiency and perceived value among others are certain contributing factors. Consequently, creating customer loyalty and satisfaction is the major objective for online companies to increase profitability and maintain a competitive advantage. To do so, companies need to develop a thorough understanding of the factors contributing to e-loyalty. Shankar et al. (p. 154) state that "firms need to gain a better understanding of the relationship between satisfaction and loyalty in the online environment to allocate their online marketing efforts between satisfaction initiatives and loyalty programs". 
Reichheld and Sasser (2005) in their research suggested that increasing a business's number of loyal customers by $5 \%$ can result in a $30 \%$ to $85 \%$ increase in profitability. On this basis, Shihyu, ChiWen, and Jiun (2014) sought to explore the factors that made eloyalty one of the critical issues for online business. According to their work, the main reason is partly that customers can easily switch from one online store to another and partly because they can easily compare similar items across different online stores ( $\mathrm{Lu}$ et al., 2013). In other words, online customers can freely visit different online stores and purchase items without needing to remain with one specific online store for all purchases. As a result, low customer loyalty frequently occurs in the online context, creating difficulty in realizing a sustainable and long-term profit for e-businesses (Yen, 2010). However, the identification of factors that might affect e-loyalty has puzzled academic scholars over the last decade. Michelle et al. (2014) tried to explain the relationship between e-trust and e-loyalty.

\subsection{E-Trust and E-Loyalty}

This article follows the work of McKnight and colleagues (e.g., McKnight \& Chervany, 2001; McKnight et al., 2002) in defining trust as "the willingness of a party to be vulnerable to the actions of another party based on the expectation that the other will perform a particular action, irrespective of the ability to monitor or control the other party" (Mayer et al., 1995, p. 712). It has been identified as an important strategy for encouraging individuals to be loyal towards e-businesses, despite the risks involved in divulging personal and financial information during the purchase process (Bart et al., 2005). Trust building interventions - such as quick and secure transaction processing (Kim, 2008), customer advice, and privacy policies (McKnight \& Chervany, 2001; Bhattacherjee, 2002; Bart et al., 2005) - help customer to trust in the e-businesses which reflects the cognitive beliefs about the provider's ability, benevolence, and integrity. Thus trust generates affective commitment, which, in turn, may cause a customer to report an intention to visit the e-commerce website again and to consider future purchases of services or products from that ebusiness provider. On this basis, we propose that a customer who has formed requisite trusting beliefs in a specific e-business 
provider is less likely to switch to a new e-business provider due to the uncertainty and risk associated while building a relationship with the e-business provider.

\subsection{Switching Costs and E-Loyalty}

Switching costs, which induce continuance commitment, are also viewed as a key driver of E-Loyalty (Lam et al., 2004; Lin et al., 2006; Chang \& Chen, 2008; Ray et al., 2012). There are other types of switching costs like exit fees, search costs, learning costs, cognitive effort, emotional costs, equipment costs, installation and start-up costs, financial risk, psychological risk, and social risk. In the marketing literature, Burnham et al (2003) identified three types of switching costs: (1) financial switching costs (e.g., fees to break contract, lost reward points); (2) procedural switching costs (time, effort, and uncertainty in locating, adopting, and using a new brand/provider); and (3) relational switching costs (personal relationships and identification with brand and employees).

Some of these costs are easy to estimate. Exit fees include contractual obligations that must be paid to the current supplier and compensatory damages that may be awarded for breach of contract. Often, vendors combine sign-up incentives with penalties for early cancellation. Careful buyers who read the fine print should not be surprised by exit fees. Search costs and learning costs, the effort and expense required to find an alternative supplier and learn how to use the new product, are also usually expected. Dianne Cyr (2014) tried to explain the relationship between website design and e-loyalty.

\subsection{Website Design and E-Loyalty}

E-business providers are increasingly concerned about how to best attract and retain satisfied, trusting and loyal customers. It is important that users perceive websites as appropriate, private and secure if they are to be revisited. According to Reichheld and Schefter (2000), an increase in customer retention rates by only $5 \%$ can increase profits by anything from 25 to $95 \%$. Further, return on investment (ROI) related to the creation of effective user experiences is substantial: an increase of $10 \%$ in spending can lead to an $83 \%$ gain in profitability (Neilson, 2008). Therefore, the 
development of e-loyalty through effective website design is a valued goal for Chief Information Officer (CIOs), as well as for managers, marketers, and strategists. In this research, the authors are examining the impact of the design elements of e-commerce websites that help to retain user satisfaction and in turn e-loyalty to a greater extent.

The above factors are the most vital for e-loyalty. Thus, the customer satisfaction construct gained through website design, switching costs, delivery efficiency along with the e-trust construct which is gained through online security and online privacy with subscales contributes to e-loyalty. This way we can retain the customers and ensure the revisiting of the e-commerce website by the customers.

\subsection{Research Gap}

One can find many research papers on e-trust, customer satisfaction, and factors influencing the e-loyalty. But there are no papers that measure the mediating role of customer experience on e-loyalty. This research paper explores the role of e-trust and customer satisfaction determining e-loyalty with the mediating role of customer experience.

\subsection{Research Hypotheses}

H1: Customer satisfaction will positively influence e-loyalty.

H1(a): Products will positively influence customer satisfaction.

H1(b): Switching costs will positively influence customer satisfaction.

H1(c): Website design will positively influence customer satisfaction.

H2 (a): E-trust will positively influence e-loyalty.

$\mathrm{H} 2$ (b): Online privacy is positively associated with e-trust.

$\mathrm{H} 2$ (c): Online security is positively related with e-trust. 


\subsection{Conceptual Framework}

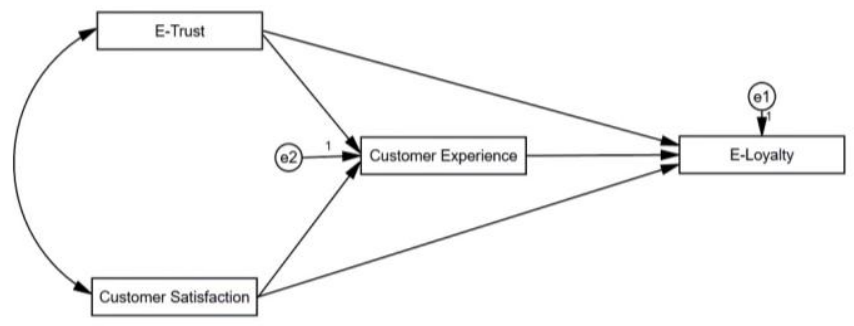

\section{Research Methodology}

\subsection{Research Design}

The research was conducted by testing the field study and survey data collected online through emails and social networking sites to sample from the huge population in India that purchase online. Also, to increase the response rate, this study follows prior studies' suggestions (e.g. Brown \& Venkatesh, 2005; Lee et al., 2013) by offering USB flash disks and gift vouchers as an incentive to encourage subjects to provide validated responses.

\subsection{Research Instrument}

We used the online questionnaire instrument to collect the data consisting of the five-point Likert scale. The scale of switching casts had three items and the scale of web design had five items. The scale of delivery efficiency had three items, the scale of online security had two items, scale of online privacy had two items, and the scale of e-satisfaction was from Fang et al.'s (2011) four items. The scales for e-trust and e-loyalty were adapted from Horppu et al.'s (2008) had four items. The scale of customer experience had two items. On the scale 1 means strongly disagree, 2 means disagree, 3 means neutral, 4 means agree, 5 means strongly agree.

\subsection{Reliability Test}

Instrument reliability was tested using Cronbach's alpha technique and all values ranged from 0.58 to 0.86 for the e-loyalty items and 0.85 to 0.93 for market response outcomes, providing internal consistency. In this research, the Cronbach alpha's value is 0.822 
which shows that the data is good and reliable because Cronbach alpha's value should be greater than 0.7 .

\begin{tabular}{cc}
\hline \multicolumn{2}{c}{ Reliability Statistics } \\
\hline Cronbach's Alpha & No. of Items \\
.822 & 8 \\
\hline
\end{tabular}

\subsection{Sampling Design}

I. Area of study: The geographic area for this study is IMCU (Kengeri campus).

II. Period of study: The idea of this research paper was generated in January mainly due to the problem that the researchers faced while ordering products from an ecommerce website. Therefore, they started working on the paper in January by conducting literature reviews, collecting the data through questionnaires and by March, 2018 they collected the data and completed the analysis.

III. Sample size: As the area of study is IMCU (Kengeri campus) the researchers calculated the sample size of 286 from the huge population which consisted of students, teaching and non-teaching staff of different age groups.

\subsection{Sampling Technique}

Random sampling is used for the analysis. The researchers took a sample of 287 from the total population of 1000 .

\subsection{Statistical Tools}

The statistical tools used in this research paper are:

1. Descriptive statistics

Frequency

2. Correlations

3. Linear Regression

4. Annova

5. KMO test 
Uppala Amulya Mediating Roles of Customer Experience on E-Loyalty

6. Cronbach alpha

7. Path Analysis

\section{Results and Discussions}

\subsection{Descriptive Statistics}

\begin{tabular}{|c|c|c|c|c|c|c|c|}
\hline \multicolumn{8}{|c|}{ Statistics } \\
\hline & $\begin{array}{c}\mathrm{Ag} \\
\mathrm{e}\end{array}$ & $\begin{array}{c}\text { Nam } \\
\mathrm{e}\end{array}$ & $\begin{array}{c}\text { Gende } \\
r\end{array}$ & $\begin{array}{l}\text { Reasons } \\
\text { for } \\
\text { online } \\
\text { shoppin } \\
\text { g } \\
\end{array}$ & $\begin{array}{c}\text { Frequenc } \\
\text { y of } \\
\text { online } \\
\text { purchase }\end{array}$ & $\begin{array}{l}\text { Average } \\
\text { cost of } \\
\text { purchas } \\
\text { e }\end{array}$ & $\begin{array}{c}\text { People and } \\
\text { activities } \\
\text { contribute } \\
\mathrm{d} \text { to } \\
\text { purchase }\end{array}$ \\
\hline Valid & 286 & 286 & 286 & 286 & 286 & 286 & 286 \\
\hline $\begin{array}{l}\text { Missin } \\
\mathrm{g}\end{array}$ & 0 & 0 & 0 & 0 & 0 & 0 & 0 \\
\hline
\end{tabular}

\begin{tabular}{|c|c|c|c|c|c|}
\hline \multicolumn{6}{|c|}{ Age } \\
\hline & & Frequency & Percent & Valid Percent & $\begin{array}{c}\text { Cumulative } \\
\text { Percent }\end{array}$ \\
\hline \multirow[t]{3}{*}{ Valid } & $20-25$ years & 169 & 59.1 & 59.1 & 59.1 \\
\hline & $26-30$ years & 117 & 40.9 & 40.9 & 100.0 \\
\hline & Total & 286 & 100.0 & 100.0 & \\
\hline
\end{tabular}

This table indicates how many people are in the age-group of 20-25 years and 26-30 years. According to the table, 169 people are in the age group of 20-25 years and 117 people are in the age group of 2630 years.

\begin{tabular}{|c|c|c|c|c|c|}
\hline \multicolumn{6}{|c|}{ Gender } \\
\hline & & Frequency & Percent & Valid Percent & $\begin{array}{c}\text { Cumulative } \\
\text { Percent }\end{array}$ \\
\hline \multirow[t]{4}{*}{ Valid } & Female & 156 & 54.5 & 54.5 & 54.5 \\
\hline & male & 5 & 1.7 & 1.7 & 56.3 \\
\hline & Male & 125 & 43.7 & 43.7 & 100.0 \\
\hline & Total & 286 & 100.0 & 100.0 & \\
\hline
\end{tabular}




\begin{tabular}{|c|c|c|c|c|c|}
\hline \multicolumn{6}{|c|}{ Reasons for Online Shopping } \\
\hline \multirow{8}{*}{ Valid } & & Frequency & Percent & Valid & Cumulative \\
\hline & & & & Percent & Percent \\
\hline & Cheaper price & 111 & 38.8 & 38.8 & 38.8 \\
\hline & Discounts & 111 & 38.8 & 38.8 & 77.6 \\
\hline & Others & 9 & 3.1 & 3.1 & 80.8 \\
\hline & $\begin{array}{l}\text { Persuaded by } \\
\text { existing shoppers }\end{array}$ & 19 & 6.6 & 6.6 & 87.4 \\
\hline & $\begin{array}{l}\text { Satisfied with the } \\
\text { quality of products }\end{array}$ & 36 & 12.6 & 12.6 & \multirow[t]{2}{*}{100.0} \\
\hline & Total & 286 & 100.0 & 100.0 & \\
\hline \multicolumn{6}{|c|}{ Frequency of online purchase } \\
\hline \multirow{7}{*}{ Valid } & Cheaper price & 1 & .3 & .3 & .3 \\
\hline & Once in 15 days & 63 & 22.0 & 22.0 & 22.4 \\
\hline & Once in 4 months & 65 & 22.7 & 22.7 & 45.1 \\
\hline & Once in 6 months & 18 & 6.3 & 6.3 & 51.4 \\
\hline & Once in a month & 129 & 45.1 & 45.1 & 96.5 \\
\hline & Once in a year & 10 & 3.5 & 3.5 & 100.0 \\
\hline & Total & 286 & 100.0 & 100.0 & \\
\hline
\end{tabular}

\subsection{Objective 1}

\begin{tabular}{ccccc}
\hline \multicolumn{5}{c}{ Model Summary } \\
\hline Model & $\mathrm{R}$ & R Square & $\begin{array}{c}\text { Adjusted R } \\
\text { Square }\end{array}$ & Std. Error of the Estimate \\
1 & $.922^{\mathrm{a}}$ & .876 & .875 & .6251 \\
\hline
\end{tabular}

a. Predictors: (Constant), Customer Satisfaction

R-square is also known as the coefficient of determination, or the coefficient of multiple determinations for multiple regressions. $\mathrm{R}^{2}$ of 1 indicates that the regression line perfectly fits the data. Our research shows the R-square value of 0.876 which is nearer to 1 . Hence, it perfectly fits the data.

\begin{tabular}{|c|c|c|c|c|c|c|}
\hline \multicolumn{7}{|c|}{ ANOVAa $^{a}$} \\
\hline Model & & $\begin{array}{l}\text { Sum of } \\
\text { Squares }\end{array}$ & $\mathrm{df}$ & $\begin{array}{l}\text { Mean } \\
\text { Square }\end{array}$ & $\mathrm{F}$ & Sig. \\
\hline \multirow[t]{3}{*}{1} & Regression & 107.279 & 1 & 107.279 & 593.603 & $.000^{\mathrm{b}}$ \\
\hline & Residual & 51.326 & 284 & .181 & & \\
\hline & Total & 158.605 & 285 & & & \\
\hline
\end{tabular}
a. Dependent Variable: switching costs
b. Predictors: (Constant), Customer Satisfaction 
Uppala Amulya Mediating Roles of Customer Experience on E-Loyalty

\section{Coefficients ${ }^{a}$}

\begin{tabular}{lccccc}
\hline \multicolumn{1}{c}{ Model } & $\begin{array}{c}\text { Unstandardized } \\
\text { Coefficients }\end{array}$ & & $\begin{array}{c}\text { Standardized } \\
\text { Coefficients }\end{array}$ & $\mathrm{t}$ & Sig \\
\hline 1.(Constant) & B & Std. Error & Beta & -1.718 & .087 \\
Customer & -.295 & .171 & & 24.364 & .000 \\
Satisfaction & 1.037 & .043 & .822 & & \\
\hline
\end{tabular}

\subsection{Objective 2}

\begin{tabular}{lllrrrrr}
\hline & & & Estimate & S.E. & C.R. & P & Label \\
\hline $\begin{array}{l}\text { Customer } \\
\text { Experience }\end{array}$ & $\leftarrow$ & ET & -.172 & .050 & -3.433 & $* * *$ & \\
$\begin{array}{l}\text { Customer } \\
\text { experience }\end{array}$ & $\leftarrow$ & CS & 1.083 & .053 & 20.414 & $* * *$ & \\
e-loyalty & $\leftarrow$ & ET & .160 & .038 & 4.217 & $* * *$ & \\
e-loyalty & $\leftarrow$ & CS & -.429 & .062 & -6.931 & $* * *$ & \\
e-loyalty & $\leftarrow \begin{array}{lllll}\text { Customer } \\
\text { experience }\end{array}$ & .749 & .044 & 17.009 & $* * *$ & \\
\hline
\end{tabular}

Regression Weights: (Group number 1 - Default model)

In the above table, ET= E-Trust, $\mathrm{CS}=$ Customer Satisfaction. From the table above, it can be noted that e-trust has a significant relationship with Customer Experience. Similarly, all the rest also have relationship with each other.

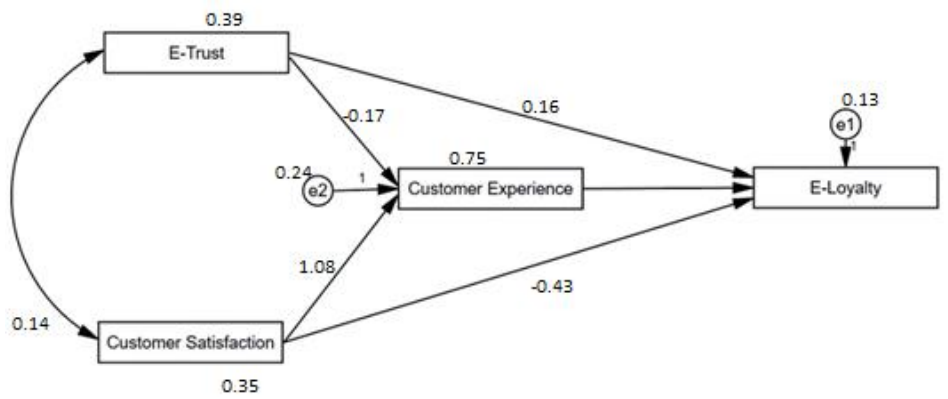

From the above figure, it can be observed that customer satisfaction has a positive relationship with customer experience (value=1.08) showing a direct, positive impact on e-loyalty whereas when we look at e-trust, it has a negative relationship with customer experience (value $=-0.17$ ) showing a negative impact 
on e-loyalty. Thus, to have a sustainable business, E-commerce should concentrate more on customer satisfaction with basic Etrust in order to have a better e-loyalty rate.

\subsection{KMO test}

\section{KMO and Bartlett's Test}

\begin{tabular}{llr}
\hline \multicolumn{2}{c}{ Kaiser-Meyer-Olkin Measure of Sampling Adequacy. } & .801 \\
\hline \multirow{3}{*}{ Bartlett's Test of Sphericity } & Approx. Chi-Square & 477.840 \\
& df & 10 \\
& Sig. & .000 \\
\hline
\end{tabular}

KMO measures sampling adequacy which should be greater than 0.5 for a satisfactory factor analysis to proceed. Kaiser recommends 0.5 as minimum (barely accepted), values between 0.7-0.8 are acceptable and values above 0.9 are superb.

As per our analysis, our sampling adequacy measure is 0.801 which lies in the acceptable range.

\section{Conclusion}

\subsection{Research Limitations}

The choice of the research design forced certain trade-offs that could limit the findings. First, the results may vary in different states and with subjects of different demographic backgrounds since the sample was collected in one particular state, and represented a certain demographic group. Further research is suggested toward expanding the study to focus on different populations. The second limitation of the study is that it hasn't distinguished different industries in testing the model. For a future study, the retail industry might be categorized since customers may have different purchase motivations for different products, thus leading to various evaluative perceptions in different retail settings. For example, online apparel shoppers might go through a different e-loyalty development process, compared to online grocery shoppers. Third, since website design has a strong effect on e-satisfaction, it is suggested to study the more diverse aspects of website design (e.g., ease of use, graphic style, information, etc.) 
in influencing e-satisfaction for future studies. In this study, the website

Design factor mainly included the navigation and information related items. Lastly, our sample did not represent the diverse cultural factors online customers maybe in. The majority of the respondents perceived high constraints on customer satisfaction, but felt they have little constraint on E-trust due to the demographic factor that we considered. In a future study, researchers might consider including respondents of different demographics in order to reflect the loyalty of the customers.

\subsection{Managerial Implications}

The process of e-loyalty development provides valuable insights for online retailers. With these results, retailers can better understand the process of establishing and directing their resources towards improving or creating e-loyalty. It is noteworthy that e-loyalty has to be based on both customer satisfaction and etrust, and the determinants of those two constructs are distinct. In managing customer e-loyalty, online retailers must consider customer satisfaction, a relational construct, e-trust, and a transactional construct concurrently in their marketing effort. In other words, customer satisfaction is enough to yield e-loyalty, but requires the partnership of e-trust. There is a mediating effect of Customer Satisfaction with the Customer Experience.

Thus, a retailer may need to pursue both transactional and relational marketing simultaneously. In addition, the results indicate that developments have to be made more for customer satisfaction with basic e-trust measures. This would enhance the customer experience and helps to increase the e-loyalty rate.

\section{References}

Anderson, R. E., \& Srinivasan, S. S. (2003). E-Satisfaction and E-Loyalty: A contingency framework. Psychology and Marketing, 20(2), 123-138.

Burnham, T.A., Judy, K. F., \& Mahajan, V. (2003). Consumer Switching Costs: A typology, antecedents, and consequences. Journal of the Academy of Marketing Science, 31(2), 109-27.

Carter, M., Wright, R., Thatcher, J. B., \& Klein, R. (2014). Understanding online customers' ties to merchants: The moderating influence of trust 
on the relationship between switching costs and e-loyalty. European Journal of Information Systems, 23(2), 185-204.

Chou, S., Chen, C. W., \& Lin, J. Y. (2015). Female online shoppers: Examining the mediating roles of e-satisfaction and e-trust on eloyalty development. Internet Research, 25(4), 542-561.

Cyr, D., Kindra, G. S., \& Dash, S. (2008). Website design, trust, satisfaction and e-loyalty: The Indian experience. Online Information Review, 32(6), 773-790.Cyr, D., Kindra, G. S., \& Dash, S. (2008). Website design, trust, satisfaction and e-loyalty: The Indian experience. Online Information Review, 32(6), 773-790.

Kim, D. J., Ferrin, D. L., \& Rao, H. R. (2009). Trust and satisfaction, two stepping stones for successful e-commerce relationships: A longitudinal exploration. Information Systems Research, 20(2), 237-257.

Lee, S. H., Noh, S. E., \& Kim, H. W. (2013). A Mixed Methods Approach to Electronic Word-of-mouth in the Open-Market Context. International Journal of Information Management, 33(4), 687-696.

Moez, L., \& Jamel, E. G. (n.d). E-Satisfaction and E-Loyalty of consumers shopping online. Journal of Internet Banking and Commerce. Retrieved from http:/ / www.icommercecentral.com/open-access/ esatisfactionand-eloyalty-of-consumers-shopping-online.php? aid=38080

Schefter, P., Reichheld, F. (2000). E-Loyalty: Your secret weapon on the web. Harvard Business Review, 78, 105-113.

Smith, E. R. (2001). Seven steps to building e-loyalty. Medical Marketing and Media, 36(3), 94-102.

Valvi, A. C., \& Fragkos, K. C. (2012). Critical review of the e-loyalty literature: A purchase-centred framework, Electronic Commerce Research, 12(3), 331-378. 